\title{
"Suíte dos pescadores": uma canção russa sobre crianças abandonadas e cães de Turguêniev
}

\author{
Marina Darmaros*
}

Na Rússia contemporânea, a música de Dorival Caymmi “Suíte dos Pescadores" (1957) é amplamente conhecida. Mas, curiosamente, sua letra vertida ao russo não tem qualquer ligação com o texto de Caymmi em português e, ao invés de um pescador colocando a jangada no mar e partindo para o trabalho, a canção russa discorre sobre meninos de rua. Trata-se, segundo o termo cunhado pelo pesquisador Peter Low, de um "replacement text": "Quando uma canção criada em uma língua é cantada em outra, seu texto será uma tradução, uma adaptação ou um 'texto de substituição'”' (LOW, 2013, p. 229, tradução nossa1).

A razão para um "texto de substituição" de conteúdo tão diverso do original deve-se, claramente, ao fato de a mentalidade russa estar intrinsecamente ligada ao filme norte-americano Capitães da Areia (em inglês, The Sandpit Generals, 1971), baseado na obra homônima de Jorge Amado. A “Suíte dos Pescadores" de Caymmi figura da trilha sonora do filme e, com o sucesso da película, a música ganhou um novo significado no imaginário russo, o que

\footnotetext{
* Doutora em Literatura e Cultura Russa pela Universidade de São Paulo (USP).

1 "When a song created in one language is sung in another, its text will be either a translation, an adaptation or a 'replacement text'."
} 
foi a causa principal de a letra não ter se difundido em tradução exata para o russo.

O filme, exibido na URSS ainda antes da publicação em russo do livro que o inspirou, fez um sucesso tão grande que marcou a memória até mesmo do atual presidente russo, Vladímir Pútin, que o menciona em um de seus vastos livros de memórias como uma referência bastante conhecida do público russo:

\begin{abstract}
Nos primeiros anos de escola, não me aceitaram entre os pioneiros ${ }^{2}$. Afinal, criei-me no pátio $^{3}$, onde a autoafirmação de uma criança se manifesta de maneira completamente diversa. Viver no pátio e criar-se nele é o equivalente a viver na selva. É muito parecido. Muito!

No pátio, a vida é livre. A vida da rua é, em si mesma, muito livre. Exatamente como no filme Capitães da Areia. Para a gente, era o mesmo. A diferença estava, talvez, apenas nas condições climáticas. Em Capitães era mais quente, e lá a garotada se reunia na praia. Mas, de resto, o que acontecia com eles e com a gente era absolutamente a mesma coisa. (PUTIN, 2002, p. 7, tradução nossa ${ }^{4}$ )
\end{abstract}

\title{
O filme cult que levou Caymmi à Rússia
}

Embora o filme Capitães da Areia não seja o tema central deste trabalho, é importante mencionar a disseminação de sua adaptação no país como introdutória à obra musical de Caymmi ${ }^{5}$. Assim como os livros amadianos em si, algumas adaptações do escritor baiano para as telas se tornaram verdadeiros

\footnotetext{
${ }^{2}$ Movimento juvenil equivalente ao dos escoteiros na União Soviética e permeado da ideologia comunista local.

${ }^{3}$ As áreas comuns entre os blocos de prédios soviéticos.

4 «В начальных классах в пионеры меня не приняли. Ведь я воспитывался во дворе, где самоутверждение ребенка выражалось совершенно в другом. Жить во дворе и в нем воспитываться - это все равно что жить в джунглях. Очень похоже. Очень!

А во дворе - свободная жизнь. Уличная жизнь сама по себе очень вольная. Совсем как в фильме "Генералы песчаных карьеров". У нас было то же самое. Разница была, наверное, только в погодных условиях. В "Генералах" было теплее, и там ребята собирались на пляже. Но в остальном, что у них, что у нас - абсолютно одинаково.»

${ }^{5}$ Cf. DARMAROS, M. Jorge Amado in the USSR: allowed printed, "dangerous" on the big screen. BrasilianaJournal for Brazilian Studies, v. 6, n. 1, p. 7-27, 8 dez. 2017. Disponível em: https://tidsskrift.dk/bras/article/view/98883/154312 e DARMAROS, M. F. Caso Jorge Amado: o poder soviético e a publicação de Gabriela, Cravo e Canela. 2020. Universidade de São Paulo, São Paulo, 2020. Disponível em: https://www.teses.usp.br/teses/disponiveis/8/8155/tde-28022020-150719/.
} 
fenômenos culturais no mundo russófono e soviético, definindo outra etapa da recepção e do gatekeepking da obra do escritor brasileiro mais conhecido da URSS.

Para entender o contexto das exibições de filmes baseados na obra amadiana entre as décadas de 1970 e 1980, utilizo a vasta pesquisa de Tatiana Nikolaevna Viétrova, chefe do departamento de cinema estrangeiro do Instituto de Arte Cinematográfica do VGIK, que aborda a questão da entrada de filmes estrangeiros e, mais especificamente, latino-americanos, para exibição nos circuitos de cinema da URSS. Para Viétrova (VIÉTROVA, 2010, p. 536-545), o motivo de o cinema latino-americano ser pouco conhecido do público soviético está intrinsecamente ligado ao sistema de distribuição local e à política da comissão de compras de filmes estrangeiros Soveksportfilm.

Até o período da Perestroika, inexistia na URSS uma distribuição para cineclubes ou cinemas especializados em filmes de arte que possibilitasse a compra de títulos em poucas cópias para exibições limitadas. Além disso, o uso do cinema para fins políticos e a falta de "elementos emotivos" tornavam alguns dos principais filmes latino-americanos pouco atraentes para o espectador soviético.

Viétrova lamenta a exibição de poucos clássicos do cinema novo brasileiro da década de 1960 no circuito soviético e lista os que entraram no circuito: em 1964, O pagador de promessas (1962, Anselmo Duarte); em 1966, Vidas Secas (1963, Nelson Pereira dos Santos) e Assalto ao trem pagador (1962, Roberto Farias). Ela também ressalta que o ícone desse período, Glauber Rocha, nunca apareceu nas telas russo-soviéticas.

Apesar de a produção brasileira não ter tido espaço na URSS até os anos 1960, sua representação nos circuitos russos no período pode ter sido mais ampla do que a mostrada por Viétrova. Além dos títulos destacados por ela, o fórum Fenix (Spissok zarubejnikh filmov, 2008) relembra uma infinidade de outros que foram dublados pelos principais estúdios soviéticos da época (Górki, 
Soiuzmultifilm, Mosfilm, Lenfilm, Dovjenko)6: de 1961, A Estrada (1956, Oswaldo Sampaio), drama com Adoniran Barbosa sobre um grupo de caminhoneiros que se rebela contra a abertura de estradas pavimentadas que serão ocupadas por grandes companhias; em 1965, Rio, 40 graus (1955, Nelson Pereira dos Santos), semidocumentário precursor do cinema novo sobre cinco meninos de uma favela do Rio de Janeiro; em 1974, Em Família (1970, Paulo Porto), sobre as dificuldades de uma família comum no sistema liberal brasileiro, no que diz respeito ao bem-estar social; em 1975, Tati (1973, Bruno Barreto), que conta a história de uma mãe solteira grávida que se muda com a filha de 6 anos de um bairro pobre do Rio de Janeiro para Copacabana; e em 1976, Jesuíno Brilhante, o cangaceiro (1972, William Cobbett), baseado na história real do cangaceiro Jesuíno Brilhante, um fazendeiro que, devido ao sistema, perde suas terras e resolve formar um grande bando de justiceiros.

A "segunda onda do novo cinema latino-americano", como classifica Viétrova, acontece por volta da década de 1980. Do Brasil, entram no circuito soviético, em 1983, Coronel Delmiro Gouveia (1979, Geraldo Sarno), em 1984, O homem que virou suco (1980, João Batista de Andrade), e, em 1986, Eles não usam blacktie (1981, Leon Hirszman), que é selecionado para a competição do Festival Internacional de Cinema de Moscou no mesmo ano.

No Fórum Fênix, ainda são mencionados no circuito de 1983 O casal (1975, Daniel Filho), com Sonia Braga, sobre um casal lidando com as primeiras dificuldades conjugais, incluindo uma gravidez inesperada e os problemas profissionais que ela causará; O grande Palhaço (1980, William Cobbett), sobre um palhaço que sai do circo deixando o filho para trás após a mulher morrer no trapézio; de 1984, Amor e Traição (1974, Pedro Camargo), sobre um peão que é

\footnotetext{
${ }^{6}$ A criadora do tópico de discussão citado no Fórum Fenix, Liudmila (sob o nickname "Salomeya8484" e que não quis ter seu sobrenome divulgado), explicou, em correspondência com a autora deste artigo, que reuniu a lista completa de dublagens realizadas durante a URSS e filmes em circuito de programações pesquisando “em revistas, anuários de cinema, catálogos comentados lançados durante a URSS, ou seja, fontes oficiais". "Esta é a lista completa dos filmes exibidos em cinemas na URSS (de 1955 a 1991). Pode ser que faltem dois ou três filmes nela, e aconteceu de alguns filmes serem dublados e não serem lançados, ou, ao contrário, serem colocados repentinamente no circuito, por isso não terem entrado nem em catálogos, nem em anuários; mas esses casos, se é que há, são adicionados à lista quando verificamos sua existência", explicou (DARMAROS, M. F., 2020).
} 
usado politicamente no Piauí após matar a mulher nos anos 1920; Na estrada da vida (1980, Nelson Pereira dos Santos), que conta a história dos cantores Milionário e José Rico; de 1986, Menino do Rio (1981, Antonio Calmon), sobre o amor entre um surfista e uma modelo rica e o preconceito social; de 1987, Independência ou morte (1972, Carlos Coimbra), que traça um perfil de Dom Pedro I e da situação política insustentável durante sua regência; de 1987, Avaeté semente da vingança (1985, Zelito Viana), sobre um grupo de pistoleiros que dizima uma aldeia indígena inteira para tomar posse das terras.

Traçado o panorama geral do cinema brasileiro nos circuitos soviéticos, é fácil depreender as temáticas que interessavam ao Soveksportfilm: eram sobretudo filmes que realçavam a crítica a um sistema liberal e capitalista, visto como decadente. Títulos de temática indígena, como foi o caso de alguns brasileiros e de muitos outros latino-americanos, também tinham sua entrada permitida nos grandes circuitos e até nas chamadas "cidades fechadas"7 soviéticas.

Os últimos alcançaram um pico de popularidade ao lado dos "sucessores do western americano" ("zameniteli amerikanskogo vesterna"), como foram chamadas as sátiras cowboys produzidas nos países socialistas europeus entre 1966 e 1977. Foram exibidos na URSS dois faroestes norte-americanos originais - Sete Homens e um Destino (1960, John Sturges) e O Ouro de Mackenna (1969, J. Lee Thompson) - , e o aparato tentava combater sua enorme popularidade com as mesmas armas.

O pesquisador Serguêi Juk (2009), que investigou os filtros culturais na cidade fechada ucraniano-soviética de Dniepropetrovsk por meio de arquivos, entrevistas e análises de diários de jovens locais entre 1964 e 1982, afirma que, para os "protetores soviéticos da pureza ideária", sobretudo em uma "cidade fechada", os filmes "indígenas" tinham papel ideológico importante. Acima de tudo, porém, estavam os títulos produzidos pelo estúdio Defa, da Alemanha

\footnotetext{
${ }^{7}$ Cidades que têm restrições de acesso devido a presença militar, indústrias nucleares ou por serem localizadas em cidades e regiões (ou áreas) de fronteira. Tanto russos como estrangeiros precisam receber autorização especial para entrar e sair dessas áreas. Sobre as "cidades fechadas", cf. o documentário City 40 (Rússia, EUA - 2016), com direção de Samira Goetschel.
} 
Oriental, que "sugeriam ao espectador soviético uma alternativa própria e socialista a uma fórmula tão popular ocidental de cinema 'burguês' como o western hollywoodiano" (JUK, 2009, tradução nossa ${ }^{8}$ ). Mas, como nota Juk, os filmes de faroeste não estavam sozinhos:

\begin{abstract}
Entre os integrantes do aparato do Partido Comunista e da KGB, a popularidade massiva desses filmes americanos era alarmante e um sinal da "perigosa imitação" das formas de cultura ocidentais entre os jovens soviéticos. Os encarregados da KGB [na cidade] notaram que "três filmes ocidentais causaram uma histeria de imitações emulações" entre os estudantes escolares e universitários de Dniepropetrovsk. Dois desses filmes eram americanos Mackenna's Gold e The Sandpit Generals - e outro, britânico - O Lucky Man!. (JUK, 2009, tradução nossa9 ${ }^{9}$ )
\end{abstract}

Assim, o realismo crítico ao capitalismo de uma adaptação baseada em uma obra de Jorge Amado também teve papel central nas preocupações dos ideólogos do socialismo. O único filme baseado na obra de Jorge Amado a entrar no grande circuito de cinemas do país durante a era soviética, de acordo com minhas pesquisas, foi The Sandpit Generals (1971). A adaptação norte-americana do diretor Hall Bartlet de Capitães da Areia foi filmada na Bahia e aparece em 1974 nas "telonas" soviéticas. Com tiragem de 1.201 cópias, a película foi uma das recordistas de público durante a era soviética, com a $34^{\circ}$ maior bilheteria entre filmes estrangeiros no país e a $100^{\circ}$ no cômputo geral, que inclui também os títulos nacionais, de acordo com dados coletados pelo crítico e professor de cinema Serguêi Valentínovitch Kudriávtsev (2006). O filme também já havia entrado na competição principal do $7^{\circ}$ Festival Internacional de Cinema de Moscou, em 1971 (IMDB).

\footnotetext{
8 «Эти фильмы предлагали советскому зрителю свою собственную, социалистическую альтернативу такой популярной форме западного “буржуазного” кино, как голливудский вестерн.»

9 «Среди аппаратчиков компартии и КГБ массовая популярность таких американских фильмов была тревожным знаком “опасного подражания” западным культурным формам среди советской молодежи. Уполномоченные КГБ отметили, что “три западных кинофильма произвели настоящую истерию подражания” среди днепропетровских школьников и студентов вузов. Два из этих фильмов были американские - Золото Маккены и Генералы песчаных карьеров, и один британский - О счастливчик!»
} 
Lançado nos EUA por vezes também como The Defiant, e outras como The Wild Pack, o filme nunca alcançou em casa o sucesso soviético. Na URSS, o título ficou tão conhecido que inspirou montagens teatrais, novas obras, reportagens especiais sobre a juventude criminosa pós-soviética ${ }^{10}$, e até nomes de batismo de gangues juvenis em Ulan-Ude, no Extremo Oriente russo (BADMAEV, 2002, p. 93-97).

É notável também o fato de que, quando o filme alcançou sucesso no país, a obra literária, de 1937, ainda não havia saído em russo. Capitães de Areia foi impresso no país, pela primeira vez, somente em 1976, dividido em duas edições da revista Molodaia Gvárdia - antes disso, apenas um trecho de 11 páginas havia sido publicado na revista Vzaschitu mira.

O filme The Sandpit Generals, em sua enorme popularidade entre 1973 e 1975, foi depositário de muitas queixas do aparato, como mostra Juk (2009) em seu estudo de caso em Dniepropetrovsk. O pesquisador cita, por exemplo, entrevista de um oficial aposentado da KGB local que, em maio de 1991, afirma: "Nossa juventude imitava cegamente os modelos antissociais de comportamento dos protagonistas de seus filmes prediletos, cowboys norteamericanos e jovens delinquentes do The Sandpit Generals" (apud JUK, 2009, tradução nossa $\left.{ }^{11}\right)$.

Foi justamente devido à crítica evidente ao "modo de vida capitalista, fadado ao sofrimento, ao crime e à morte de crianças de rua inocentes que o filme entrou para a competição do festival de Moscou em 1971, apresentado como progressista" (JUK, 2009, trad. nossa ${ }^{12}$ ).

Em Dniepropetrovsk, o filme foi exibido pela primeira vez em 1973, tornando-se o título mais popular dos cinemas locais por dois meses. Com o

\footnotetext{
${ }^{10}$ Entre outras, uma reportagem intitulada Capitães das selvas urbanas (Guenerali gorodiskikh djunglei), à semelhança do título amadiano (que em russo foi vertido para Guenerali pestchanikh karierov), veiculada no Piérvi Kanal nos anos 1990 está disponível hoje no YouTube: https://www.youtube.com/watch?v=YxjiTloWIdo.

11 «Наша молодежь слепо подражала антиобщественным образцам поведения героев любимых фильмов, американских ковбоев и юных уголовников из Генералов песчаных карьеров.»

12 «Из-за очевидной и достаточно смелой критики "капиталистического образа жизни, обрекающего на страдания, преступления и смерть невинных бездомных детей”, этот фильм летом 1971 года был показан на VII Московском международном кинофестивале и представлен как “прогрессивный”.»
} 
sucesso alcançado, a administração local dos circuitos de cinemas decidiu manter as exibições no verão de 1974.

De acordo com Juk, os diários por ele pesquisados, de adolescentes entre os 14 e 15 anos de idade, mostraram um "entusiasmo inextinguível" pelo filme. Ele cita o trecho redigido pelo jovem local Aleksandr Gussar, em 28 de junho de 1974: “Lembro cada cena de Capitães [de Areia], mas, mesmo assim, pretendo assistir ao filme pela terceira vez amanhã, para relembrar também a música do filme" (JUK, 2009, tradução nossa'13).

O comentário de Gussar reproduz a paixão geral causada nos espectadores também pela trilha que abre o título, de Dorival Caymmi, que chega a participar do filme como coadjuvante. Juk conta que, quando a revista juvenil Rovesnik (em português, Coetâneo) publicou a letra traduzida e a partitura de "Suíte dos Pescadores", muitos fãs do filme tentavam conseguir a edição para copiá-las.

A dificuldade em encontrar a edição número 8 de $1974^{14}$, na qual foi publicado material, é um indício de que Juk tem razão. Na revista juvenil, a tradução feita por B. Senkin se aproxima bastante da temática da letra original, como veremos na próxima seção deste artigo. No texto que acompanha a partitura e a letra ainda se lê:

\begin{abstract}
Não é por acaso que o filme compõe a biografia de Hall Bartlet. Ele mesmo viveu em uma atmosfera de constante necessidade e dedicou seis de seus onze filmes às vidas dos menos afortunados. [...] Foi o próprio Bartlet quem financiou o filme, convidando para a trilha o compositor brasileiro Dorival Caymmi, amigo de Jorge Amado e compositor de toda uma série de ciclos de músicas de pescadores. Publicamos nesta edição a música principal da trilha sonora a pedido de nossos leitores. (SENKIN, 1974, p. 23, tradução nossa ${ }^{15}$ )
\end{abstract}

\footnotetext{
13 «Я помню каждую сцену из Генералов (песчаных карьеров), но все равно я собираюсь смотреть этот фильм третий раз завтра, чтобы запомнить и песню из этого фильма.»

${ }^{14}$ Em coleções de revistas à venda em sebos e nas coleções digitalizadas que abundam na internet russa, a edição está constantemente ausente. Agradeço aos funcionários da Biblioteca Lênin, em Moscou, que em pleno lockdown (devido à pandemia do coronavírus) digitalizaram e me enviaram a página supracitada.

15 «Фильм этот не случаен в биографии Холла Бартлета. Он сам вырос в атмосфере постоянной нужды и шесть из своих одиннадцати фильмов посвятил жизни обездоленных. [...] Бартлет сам финансировал
} 


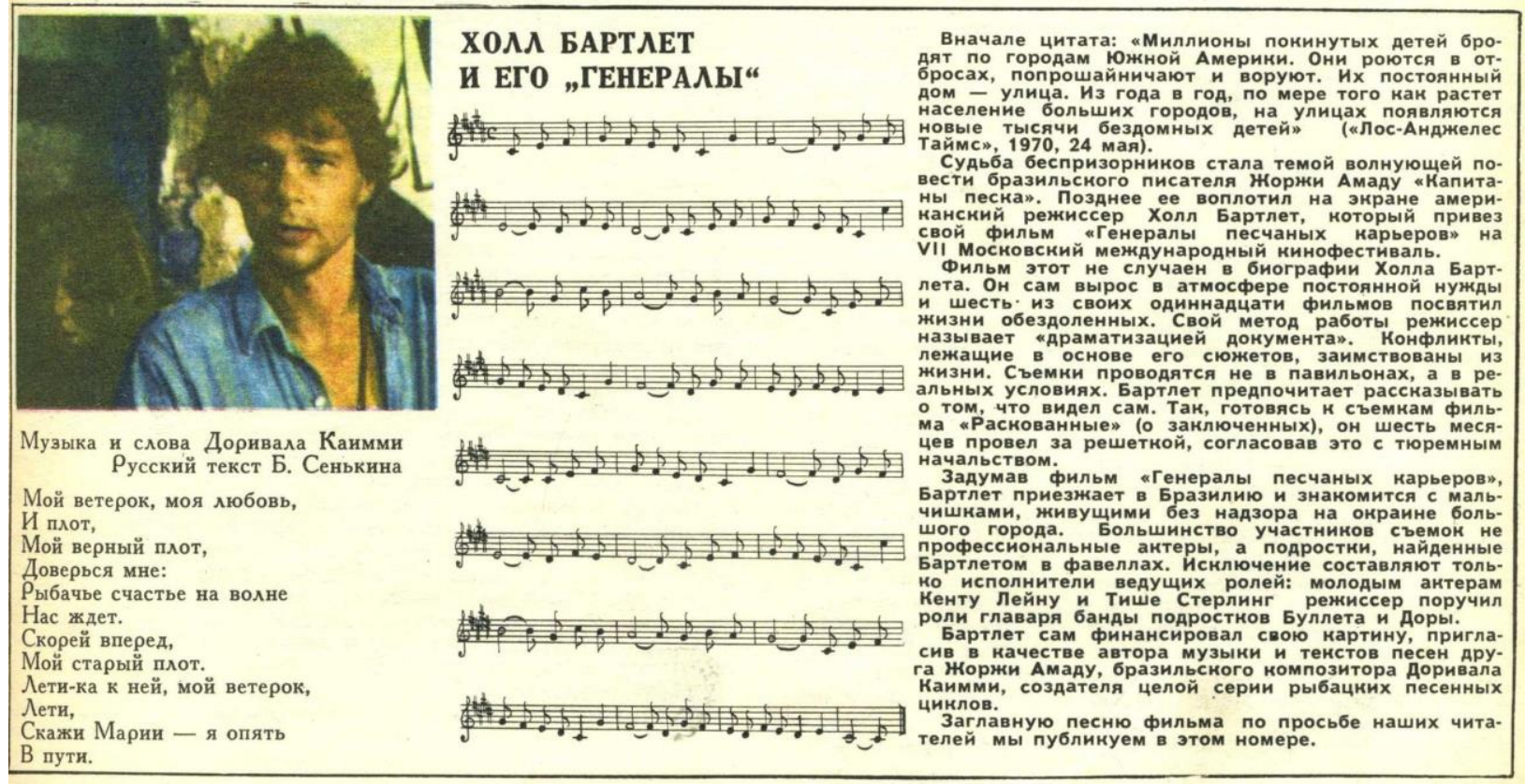

Recorte da revista Rovesnik No 8 de 1974, com tradução e cifra da "Suíte dos Pescadores".

Posteriormente, a canção ganhou uma versão russa feita pelo poeta e músico Iúri Vladímirovitch Tseitlin (1915-1996), como escreve o jornalista Serguêi Komarítsin (KOMARITSYN, 2011). Mas Marat Djumagaziev, colaborador do portal literário Stikhí, analisou seu conteúdo e é crítico quanto à produção:

Sem saber a letra da canção em português, mas impressionado com o filme, o músico de jazz Iúri Tseitlin inventou, nos anos 1970, sua própria variação sentimental russa para o então popular quarteto Akkord [...]. No final dos anos 1990, a melodia brasileira com o texto de Tseitlin foi retomada com êxito pelo grupo Nestchástni slútchai (1997), e foi cantada pelos protagonistas do famoso seriado Brigada (2002), além de diversos outros cantores. Mas, na verdade, a

свою картину, пригласив в качестве автора музыки и текстов песен друга Жоржи Амаду, бразильского композитора Доривала Каимми, создателя целой серии рыбацких песенных циклов. Заглавную песню фильма по просьбе наших читателей мы публикуем в этом номере.» 
música não trata de crianças abandonadas, e sim de pescadores que vão para o mar. (DJUMAGAZIEV, 2006, tradução nossa ${ }^{16}$ )

Portanto, a impressão causada pela produção cinematográfica foi estrondosa. Em seu estudo de caso, Juk (2009) relata que membros do partido e da juventude comunista em Dniepropetrovsk expressavam preocupação quanto ao aumento dos crimes entre jovens nos anos 1970, e relacionavam-nos diretamente à influência causada pelo filme Capitães. Na cidade, de acordo com dados oficiais, 28 mil jovens cometiam crimes por ano - desses, $72 \%$ tinham até 25 anos de idade. Muitos deles, segundo dados da polícia, diziam se identificar com os bandidos de Mackenna's Gold ou de Capitães. Os oficiais ressaltavam ainda o "fator emocional" exercido pela música de Capitães e a polícia lamentava a difusão de "formas estrangeiras de luta e combate corpo-a-corpo". Segundo eles, muitos dos jovens criminosos diziam ter sido o filme Capitães sua principal fonte de informação sobre essas lutas, e citavam a capoeira.

Se a produção teve uma péssima recepção pelo aparato oficial, verdade é que se tornou um mito entre espectadores das mais diversas faixas etárias ${ }^{17}$. Ao pincelar as adaptações para cinema e TV da obra amadiana, a pesquisadora da Universidade de Tcherepovets Elena Beliakova afirma que:

The Sandpit Generals tornou-se parte da mentalidade russa. O filme ainda é visto hoje em vídeo e em DVD. A própria expressão ${ }^{18}$ tornou-se comum: agora, [na

\footnotetext{
16 «Не зная португальского текста песни, но под впечатлением увиденного фильма советский джазовый музыкант Юрий Цейтлин в 70-тых годах придумал собственный слезливый русский вариант для популярного тогда квартета "Аккорд" [...] В конце 90-тых годов бразильскую мелодию с текстом Цейтлина успешно реанимировала группа "Несчастный случай" (1997), её пели герои известного сериала "Бригада" (2002) и ещё ряд исполнителей. Но на самом деле это песня не о беспризорниках, а о рыбаках, вышедших в море.»

${ }^{17}$ A BBC mencionou o fenômeno há alguns anos em reportagem: http://www.bbc.com/portuguese/noticias/2012/08/120806_amado_capitaes_filme_tp.shtml

${ }^{18}$ Aqui, a pesquisadora se refere à expressão "capitães da areia". Isso se justifica pelo fato de o filme em russo ter sido adicionado de um letreiro na abertura, inexistente no original norte-americano, em que se lê: “'Milhões de crianças abandonadas perambulam pelas cidades da América do Sul. Elas vivem remexendo o lixo, mendigando e roubando. Sua residência permanente é a rua. De ano em ano, enquanto cresce a população, aparecem mais milhares de crianças nas ruas' (Los Angeles Times, 24 de maio de 1970). No Brasil, essas crianças são conhecidas já há muitas gerações como 'capitães da areia'".
} 
Rússia,] as crianças de rua de qualquer país são chamadas somente assim ['capitães da areia']. Em geral, esse filme sobre equidade é considerado cult. (Beliakova, 2010, p. 140-141, tradução nossa ${ }^{19}$ )

\title{
Versão original, "consagrada" e traduções
}

Dado o contexto histórico da canção de Caymmi e de sua popularidade na Rússia e na União Soviética, proponho-me aqui a analisar comparativamente sua letra original à que ficou consagrada em russo, assim como a outras propostas de tradução. Seguindo a teoria de Low (2013, p. 230, trad. nossa), não utilizarei o termo "tradução" ao me referir a "versões nas quais foram tomadas liberdades com detalhes significativos, ou seja, textos de chegada que trazem acréscimos, omissões e/ou outros desvios". O caso com a canção consagrada de Iúri Tseitlin, porém, não se trata tampouco de adaptação.

\begin{abstract}
Nem mesmo o termo mais livre "adaptação" pode acomodar um fenômeno que vai mais além: o de todo um novo texto que é inventado para ser cantado sobre uma melodia preexistente. Como letra musical, ele lembra uma tradução ou adaptação musical. Mas difere delas por ser não derivativa. Tais textos podem até mesmo ser criados por mestres da escrita que não conhecem a língua de partida. Para esses, propõe-se o termo "texto de substituição". No contexto musical, um "texto de substituição" será definido aqui como uma letra musical criada para ser usada com uma melodia preexistente, apesar de não manifestar qualquer transferência semântica do texto anteriormente cantado com aquela melodia. (LOW, 2013, p. 231, tradução nossa ${ }^{20}$ )
\end{abstract}

\footnotetext{
19 "А «Генералы песчаных карьеров» стали частью нашего русского менталитета. Фильм по-прежнему смотрят, правда, теперь на видео и DVD. Само словосочетание стало нарицательным: теперь беспризорников любой страны только так и называют. В общем, фильм по справедливости считается «культовым»."

20 "Yet even the freer term 'adaptation' cannot accommodate a further phenomenon: the entirely new text which is devised to be sung to an existing tune. As a song lyric, it resembles a song translation or song adaptation. But it differs from them by being non-derivative. Such texts can even be created by wordsmiths who do not know the source language. For these, the term 're-placement text' is proposed. In the context of songs, a 'replacement text' will be defined here as a song lyric created to be used with a pre-existing melody, yet manifesting no semantic transfer from the text previously sung to that melody".
} 
Assim, a letra proposta por Tseitlin é genuinamente um "texto de substituição", como podemos notar a partir de sua comparação com a original, que se segue:

\author{
Suíte dos Pescadores (Dorival Caymmi) \\ Minha jangada vai sair pro mar \\ Vou trabalhar, meu bem querer \\ Se Deus quiser quando eu voltar do mar \\ Um peixe bom eu vou trazer
}

Meus companheiros também vão voltar

E a Deus do céu vamos agradecer

\begin{abstract}
Adeus, adeus
Pescador não esqueça de mim

Pra não ter tempo ruim

Vou fazer sua caminha macia

Perfumada com alecrim

A estrela d'alva me acompanha

Iluminando o meu caminho

Eu sei que nunca estou sozinho

Pois tem alguém que

Está pensando em mim
\end{abstract}

Vou rezar pra ter bom tempo, meu nego

A versão de Tseitlin dos anos 1970, imortalizada pelo grupo Nestchástni slútchai (1997) ${ }^{21}$ em contexto diverso, como parte de um programa de TV intitulado Stárie piêsni o glávnom (Velhas músicas sobre o que é importante), seguese abaixo com retradução nossa ao português:

\footnotetext{
${ }^{21} \mathrm{O}$ videoclipe, produzido pelo programa de TV no primeiro pavilhão dos estúdios da Mosfilm, tem uma inusitada introdução que faz referência ao filme de 1975 Zdravstvuite, ia vasha tiôtia (em tradução livre, Olá, eu sou sua tia), outro marco no imaginário russo sobre o Brasil. Produzido com base no roteiro de Brandon Thomas Charley's Aunt, o filme conta a história de um desempregado que, para fugir da polícia, que o persegue por "vagabundagem", se veste de mulher e entra em uma casa abastada fingindo ser uma tia distante que mora no Brasil, Dona Rosa d'Alvadorez, em visita. O clipe da música está disponível no YouTube: https://www.youtube.com/watch?v=r3KJMAi04fM
} 
Генераль песчаньх карьеров (Юрий Цейтлин)

Я начал жизнь в трущобах городских, И добрых слов я не слыхал.

Когда иаскали вы детей своих, Я есть просил, я замерзал.

Вы, увидав меня, не прячьте взгляд

Ведь я ни в чём, ни в чём не виноват. За что вы бросили меня, за что? Где мой очаг, где мой ночлег? Не признаёте вы моё родство, А я ваш брат, я человек.

Вы вечно молитесь своим богам, И ваши боги всё прощают вам. Край небоскребов и роскошных вилл, Из окон иьёт слепящий свет. $\mathrm{O}$, если б мне хоть раз набраться сил, Вы дали б мне за всё ответ. Откройте двери, люди, я ваш брат Ведь я ни в чём, ни в чём не виноват. Вы знали ласки матерей родных, А я не знал и лишь во сне, В моих мечтаньях детских золотых Мать иногда являлась мне. О мама, если бы найти тебя, Была б не так горька моя судьба.
Capitães da Areia (Iúri Tseitlin)

Minha vida se iniciou nas favelas da cidade

E não escutei palavras amáveis.

Quando vocês faziam carinho em seus filhos,

Eu pedia comida e passava frio.

Ao me ver, não escondam o olhar

Já que não tenho culpa de nada, nada.

Por que vocês me abandonaram, por quê?

Onde está meu lar, minha pousada?

Vocês não reconhecem meu parentesco,

E sou seu irmão, sou uma pessoa.

Vocês rezam eternamente a seus deuses,

E seus deuses perdoam tudo a vocês.

Uma região de arranha-céus e vilas luxuosas

Da janela vaza uma luz cegante.

Oh, se ao menos uma vez eu conseguisse juntar forças,

Vocês me dariam resposta para tudo.

Abra a porta, gente, sou seu irmão

Já que não sou culpado de nada, nada.

Vocês conheceram os carinhos de mãe,

Mas eu não conheci e apenas em sonho,

Em meus sonhos dourados infantis

Minha mãe se revelava a mim.

Oh, mamãe, se eu a encontrasse

Meu destino não seria tão amargo.

\section{O autor da versão supracitada, Iúri (Gueórgui) Vladímirovitch Tseitlin,} era filho de uma georgiana e cresceu em Tbilisi. Apesar de conhecer diferentes realidades ${ }^{22}$, não há indícios de que Tseitlin soubesse português, vertendo, assim, a letra de Caymmi sem qualquer fidelidade ao texto original.

\footnotetext{
${ }^{22}$ Durante a Segunda Guerra foi dispensado por problemas nos pulmões, mas lutou nas tropas irregulares. Já então foi convidado ao programa de variedades e show de Nikolai Smirnov-Sokolski Falemos sobre a Canção (Pogovorim o pesne), que tinha direção musical do jazzista Aleksandr Varlamov. De lá, partiu para a Orquestra de Jazz da República da Bielorrússia (sob o comando de Eddie Rosner entre 1942 e 1946). Foi para a frente de guerra no corpo da brigada artística. Durante esses anos, escreveu letras para as músicas de Albert Harris e Posner. De 1946 a 1953, dirigiu o clube de jazz moscovita Cozinheiros engraçados (Vesiolie povara), onde apresentava os shows e tocava trompete. Em 1954, Rosner criou um novo grupo de jazz, no qual Tseitlin tocava trompete. A parceria se estendeu até 1959. Na década de 1960, dedicava-se sobretudo à criação literária, escrevia programas para concertos, folhetins (por exemplo, com a renomada revista satírica "Krokodil"),
} 
Sobre essa versão, o próprio Danilo Caymmi, filho de Dorival, comentou, em entrevista a autora deste artigo:

Cansei de ver vídeos de misséries que mandaram para mim da Rússia [com a "Suíte dos Pescadores" na trilha]. A música é altamente popular, e chegou um momento a ser atribuída até ao Michel Teló, que faz muito sucesso por lá. Uns anos atrás eu estava em um hotel em São Paulo e quando eu desci na portaria um rapaz que morou na Rússia me contou várias histórias, e uma delas era que essa canção foi adotada - e isso é até algo difícil de verificar - pela máfia russa. Então, os soldados que deixaram o Afeganistão - perderam a guerra e voltaram para a Rússia - eram muito segregados e cantavam essa música. (DARMAROS, 2020)

Tamanha foi a popularidade do filme The Sandpit Generals na União Soviética, como vimos anteriormente, que não só a letra de Tseitlin se consagrou ali, como também outras, as chamadas "versões de pátio" ("dvoróvie versii") já que criadas nos mesmos pátios mencionados por Putin. $O$ usuário "Karasiatnik", do Live Journal, plataforma de blogues de grande sucesso na Rússia nos anos 2000, listou seis dessas letras ${ }^{23}$, complementadas ainda por outras relembradas por leitores nos comentários. Todas elas são textos de substituição que remetem ao imaginário russo e estereótipos sobre o Brasil ou ao conteúdo do livro Capitães da Areia, de Amado - como, por exemplo, a cena da morte de Dora.

Como vimos anteriormente, à época da popularização da versão de Tseitlin, a revista Rovesnik também já havia publicado uma versão mais próxima da original (e, talvez por isso, menos popular), de B. Senkin (1974), que apresentamos e retraduzimos ao português a seguir:

músicas folclóricas eslavas de paródia do gênero "tchastúchka" e letras para outras músicas, firmando parceria estreita com o quarteto Akkord (que existiu entre 1960 e 1988).

${ }^{23}$ Cf. https://karasyatnik.livejournal.com/86676.html 


\begin{tabular}{|c|c|c|}
\hline $\begin{array}{l}\text { Minha jangada vai sair pro mar } \\
\text { Vou trabalhar, meu bem querer } \\
\text { Se Deus quiser quando eu voltar do } \\
\text { mar } \\
\text { Um peixe bom eu vou trazer } \\
\text { Meus companheiros também vão } \\
\text { voltar } \\
\text { E a Deus do céu vamos agradecer } \\
\text { Adeus, adeus } \\
\text { Pescador não esqueça de mim } \\
\text { Vou rezar pra ter bom tempo, meu } \\
\text { nego } \\
\text { Pra não ter tempo ruim } \\
\text { Vou fazer sua caminha macia } \\
\text { Perfumada com alecrim }\end{array}$ & $\begin{array}{l}\text { Мой ветерок, моя дюбовь, } \\
\text { И плот, } \\
\text { Мой верный плот, } \\
\text { Доверься мне: } \\
\text { Рыбачье счастье на волне } \\
\text { Нас ждет. } \\
\text { Скорей вперед, } \\
\text { Мой старый плот. } \\
\text { Дети-ка к ней, мой ветерок, } \\
\text { Дети, } \\
\text { Скажи Марии - я опять } \\
\text { В пути. }\end{array}$ & $\begin{array}{l}\text { Minha brisa, meu amor, } \\
\text { E a jangada, } \\
\text { Minha fiel jangada, } \\
\text { Confie em mim: } \\
\text { A felicidade dos pescadores na onda } \\
\text { Nos aguarda. } \\
\text { Depressa, adiante, } \\
\text { Minha velha jangada. } \\
\text { Voe de volta ela, minha brisa, } \\
\text { Voe, } \\
\text { Diga a Maria que eu estou de novo } \\
\text { A caminho. }\end{array}$ \\
\hline
\end{tabular}

Mais recentemente, porém, outra versão com letra completamente diversa da original ganhou fama na Rússia: a do compositor Aleksêi Kôrtniev. Intitulada "Para que Guerassim afogou Mumu"? (Za tchto Guerassim utopil Мumu?)24, ela tem texto de substituição que remete ao conto "Mumu" (1854), de Ivan Turguêniev, sobre um cachorro morto pelo dono a mando da patroa.

Para Low (2013, p. 239, tradução nossa ${ }^{25}$ ),

um dos motivos para se criar textos de substituição é óbvio: se uma pessoa vê méritos em uma melodia musical existente, mas acha a letra fraca, batida ou boba, ela pode muito bem tentar escrever uma letra melhor. Mas isto não é traduzir, e já argumentei em outro espaço que tais práticas não têm lugar em discussões sobre tradução.

Apesar disso, como relembra o próprio Low, diversos pesquisadores têm incluído os "textos de substituição" como objeto de pesquisa na temática dos Estudos da Tradução. Em uma edição especial da publicação The Translator on

$24 \mathrm{O}$ próprio Kôrtniev toca sua versão em um programa de TV neste vídeo disponível no YouTube: https://www.youtube.com/watch?v=_GqDuBt_S4g

25 "One reason for making replacement texts is obvious: if one sees merit in an existing song tune but finds the lyric weak, trite or silly, then one may very well try to write better words. But that is not translating, and I have argued elsewhere that "such practices have no place in discussions of translation". 
Translation and Music, por exemplo, a editora-convidada Sebnem SusamSarajeva (SUSAM-SARAJEVA, 2008, p. 189) reconheceu que o ponto de vista de Low "podia ser compartilhado por muitos profissionais/pesquisadores na área", mas, mesmo assim, era uma opinião demasiado inflexível, relembrando diversos artigos naquela mesma edição que analisavam e discutiam "textos de substituição" no discurso acadêmico sobre tradução. Para Low, porém, esse tipo de texto é uma manifestação de comunicação intercultural não porque tenha havido qualquer tradução ou adaptação, e sim porque seus componentes musicais foram apropriados:

Eles podem até merecer ser estudados como exemplos do marketing musical internacional, no contexto da globalização da cultura popular. Mas apesar de outros terem o desejo de declarar que as músicas são as mesmas, eu argumentaria que qualquer definição estrita de música requer os dois componentes: letra e melodia. Quando um texto de substituição é corrompido em uma melodia, a música deixa de ser a mesma, e chamar a nova letra de tradução ou adaptação é algo falso e possivelmente antiético. (LOW, 2013, p. 240, tradução nossa ${ }^{26}$ )

Porém, no caso da versão mais consagrada de "Suíte dos Pescadores" em russo - aquela de Tseitlin imortalizada pelo grupo Nestchástni slútchai e pela minissérie Brigada - o elemento "possivelmente antiético" mencionado por Low é, talvez, minimizado pelo fato de que Dorival Caymmi sequer soube de alguma regravação ou da fama da música no país - e tampouco recebeu os royalties devidos - , segundo seu filho, Danilo Caymmi.

Acho que meu pai não sabia da popularidade da música na Rússia. [...] Na Rússia, por conta da máfia, eles tinham duas associações de direitos autorais, mas uma eliminou a outra. Literalmente! Então é muito difícil de receber em qualquer lugar do mundo direitos autorais provenientes da Rússia. Eu até

\footnotetext{
26 "They may even merit study as examples of the international marketing of music, in the context of the globalization of popular culture. But though others may wish to declare that they are still the same songs, I would argue that any strict definition of song requires the two components of words and music. When a replacement text is grafted onto a tune, it ceases to be the same song, and to call the new song lyric a translation or adaptation is false and may be unethical."
} 
gostaria e já até tentei: fiz parte da diretoria da associação Abramus aqui no Brasil e estou totalmente por dentro do direito autoral [...] Mas, enfim, não consegui nada. (DARMAROS, 2020)

É interessante notar que a Abramus (Associação Brasileira de Música e Artes), à qual ele se refere, é uma "associação de gestão coletiva de Direitos Autorais", como define o próprio site da instituição (ABRAMUS, 2020). Mas os direitos autorais na Rússia são um caso à parte, já que Moscou se tornou conhecida pela prática de traduzir e publicar livros de estrangeiros sem nada pagar - e isto se estendia também à reprodução fonográfica - , por não ser signatária da Convenção de Berna de 1886, que estabeleceu o reconhecimento dos direitos autorais entre nações soberanas. Muito antes da convenção, a Rússia já tinha acordos sobre direitos no campo da literatura e das artes, em 1861 com a França e em 1862 com a Bélgica, mas, após o tratado de Berna, os dois foram cancelados, em 1887. Assim, após sua ausência no tratado como Império Russo e como União Soviética, a Federação da Rússia somente entrou para a Convenção de Berna em 13 de março de 1995. Mas a tradição de não pagar os royalties, na prática, se manteve em diversos casos, como o de Caymmi27.

No caso de Caymmi, para além dessas versões "consagradas", houve também diversas tentativas de adaptação e tradução da letra para o russo, muitas delas disponibilizadas na internet em blogues e sites literários, como é o caso do supracitado Marat Djumagaziev (2006), em versões integrais ou parciais. E, apesar de nenhuma delas ter ganhado a notoriedade das "versões de pátio" ou do consagrado texto de substituição de Tseitlin, analisaremos algumas a seguir:

\footnotetext{
27 Tão bem conhecida é, aliás, a relação da Rússia com os direitos autorais, que os livros da Gallimard, por exemplo, saíam com ressalvas ao país. Por exemplo, a $117^{\circ}$ edição francesa, de 1954, de L'Homme Révolté, de Albert Camus, pela Gallimard traz a seguinte inscrição sob a página de créditos da edição: “Tous droits de traduction, de reproduction et d'adaptation réservés pour tous les pays, y compris la Russie." (CAMUS, 1954, p. 9)
} 


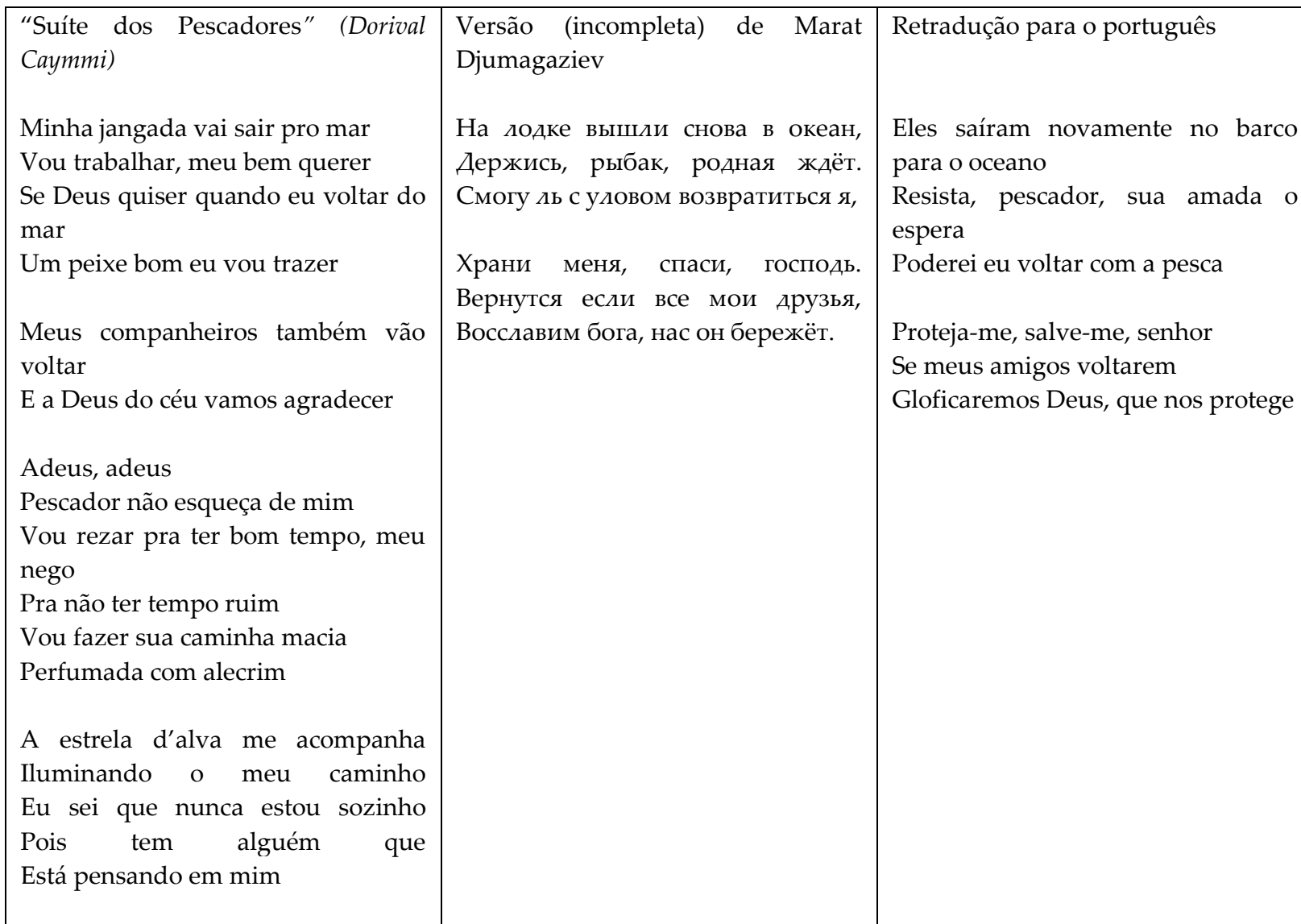

Outra versão mais completa é de autoria de Margarita Slivniak, tradutora especializada em língua e literatura inglesa e estudos hebraicos. Slivniak estudou em Leningrado, Varsóvia e Jerusalém, e é doutora em linguística. Vive atualmente em Toronto, onde é tradutora especializada em medicina, e realizou esta tradução da letra de Caymmi vencedora do concurso tradutório "Música de tradução 2014". Segundo a autora, esta foi a primeira "tradução exata da letra para a língua russa" (SLIVNIAK, 2017). 


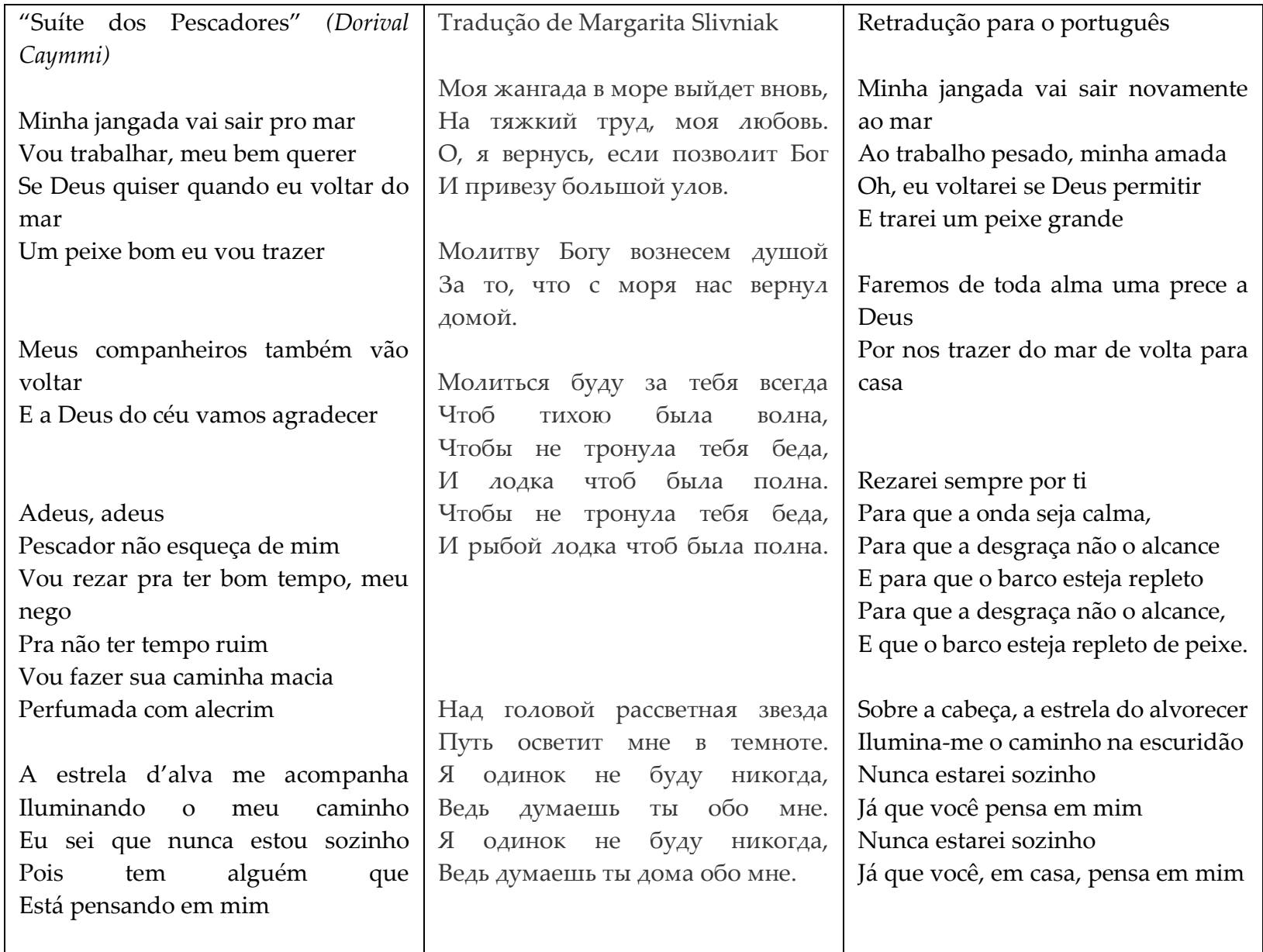

\section{Conclusão}

Não é possível falar sobre Caymmi, e muito menos de sua "Suíte dos Pescadores" na Rússia e na União Soviética, sem tratar do texto de substituição produzido por Tseitlin ou comentar a existência de suas inúmeras "versões de pátio". Conquanto as versões russas de Slivniak e Djumagaziev constituam traduções da letra original e sejam objeto de análise neste artigo, a versão de Tseitlin transpõe a ideia de substituição ao se tornar uma ponte ao imaginário russo de uma terra distante com problemas tão próximos aos que ela mesma enfrentava, em certo grau, nos anos 1970, e enfrentaria com ainda maior gravidade nos anos 1990. E, apesar da enorme fama de que Amado já gozava no 
país nos anos 1970 (DARMAROS, M.F., 2020), quando a produção de Bartlet entrou nos circuitos de cinemas russos, pode ter sido justamente a melodia de Caymmi que salvou a adaptação cinematográfica, questionável até os dias atuais e pouquíssimo conhecida, tanto no Brasil do livro Capitães da Areia, como nos Estados Unidos do filme The Sandpit Generals.

Uma usuária da plataforma de blogues Live Journal, Lilia Polênova, comenta assim a importância que a música de Caymmi teve para a popularidade da obra cinematográfica:

\begin{abstract}
Vocês se lembram deste filme idiota? O que nos arrebatou a todos nos anos 1970 neste filme fraco, sentimental e afetado? Burlávamos a recomendação "acima de 16 anos" e assistíamos umas 10 vezes. Eram as cenas sexuais? Claro que não, os filmes franceses já estavam disponíveis e tinham de tudo. O enredo? Não há ali um enredo interessante, mas uma adaptação comunista de Oliver Twist. A música? Possivelmente, sim, é a música. No original, eu não entendia em que língua eles cantavam... Em português? Com certeza não era inglês. Quantas foram as adaptações inspiradas nos acordes dos infratores nos pátios! Mas o filme é ruim. Nos EUA, ninguém o conhece, exceto os imigrantes russos. Não vale a pena assistir. Mas como um fenômeno cultural peculiar de nossa infância soviética, é divertido. (POLÊNOVA, 2012, tradução nossa ${ }^{28}$ )
\end{abstract}

Portanto, a estrondosa popularidade russa atingida pela obscura adaptação cinematográfica de Capitães da Areia, filme que não foi exibido no Brasil da ditadura militar e desconhecido no país até hoje, deve muito à música de Dorival Caymmi. E o mesmo é verdade, sem dúvida, quanto ao "texto de substituição" cunhado pelo músico Tseitlin, que marcou para sempre a composição e a película nos corações e mentes de gerações inteiras que cresceram nos pátios

28 "Помните этот дурацкий фильм? Что нас всех тогда так зацепило, в 70-е, в этом слабом, сентиментальном и напыщеном фильме? Пробирались через заслон «детям до 16», смотрели по 10 раз. Сексуальные сцены? Да нет, французские фильмы были доступны и всё там было. Сюжет? Нет там интересного сюжета, Оливер Твист в коммунистическом переложении. Песня? Наверное, все-таки песня. В оригинале я так не поняла на каком языке они поют, по-португальски? Но точно не поанглийски. Сколько было переложений, которые вдохновенно распевали во дворах под блатные аккорды! А фильм плохой. В Америке никто о нем и не знает, кроме русских иммигрантов. Не стоит его смотреть. А как своеобразный культурный феномен нашего советского детства - забавно."

Tradução em Revista 29, 2020.2 
russo-soviéticos: de cidadãos comuns a membros da máfia e duradouros presidentes.

\section{Referências}

ABRAMUS. Abramus: Quem Somos. 2020. Disponível em: https://www.abramus.org.br/sobre-a-abramus/. Acesso em: 20 jun. 2020. BADMAEV, A. Neformalnie Molodiojnie assotsiatsii v Ulan-Ude. Vestnik Evrazii, Badmaev, Andrey. Neformalnie molodyozhnie assotsiatsii v Ulan Ude, p. 90-104, 2002. Disponível em: http://eavest.ru/biblioteka/stati-iknigi/regiony/43-andrej-badmaev-neformalnye-molodezhnye-assotsiatsii-vulan-ude. Acesso em: 20 jun. 2020.

BELIAKOVA, E. Russki Amadu i brazilskaia literatura v Rossii. Moscow, ILARAN, 2010.

CAMUS, A. L'Homme Révolté. Paris, Gallimard, 1954.

DARMAROS, M. Entrevista com Danilo Caymmi. São Paulo, Rio de Janeiro. Entrevista concedida por telefone por Danilo Caymmi em 15 de junho de 2020. DARMAROS, M. F. Caso Jorge Amado: o poder soviético e a publicação de Gabriela, Cravo e Canela. 2020. 278f. Tese de doutorado defendida no Programa de Literatura e Cultura Russa da Universidade de São Paulo, São Paulo, 2020.

DZHUMAGAZIEV, M. Pesnya iz kinofilma "Generali peschanikh karierov", Brazilia - SShA. 2006. Stihi.ru. Disponível em: http://www.stihi.ru/2006/11/051261. Acesso em: 3 jun. 2016.

IMDB. 1971 Moscow International Film Festival. [S.d.]. Disponível em: http://www.imdb.com/event/ev0000450/1971. Acesso em: 15 jun. 2016.

JUK, S. Zapad v sovietskom "zakritom" gorode: "tchujoie” kino, ideologuia i problemi kulturnoi identitchnost na Ukraine v brejnevskuiu epokhu (19641982). Novoe literaturnoe obozrenie, v. $\mathrm{N}^{\circ}$ 6, 2009. Disponível em: https://magazines.gorky.media/nlo/2009/6/zapad-v-sovetskom-zakrytom- 
gorode-chuzhoe-kino-ideologiya-i-problemy-kulturnoj-identichnosti-naukraine-v-brezhnevskuyu-epohu.html. Acesso em: 20 jun. 2020.

KOMARITSYN, Sergey. Kommunist na karnavale. Gorodskie novosti, 4 nov. 2011. Disponível em: http://www.gornovosti.ru/tema/history/kommunist-nakarnavale.htm. Acesso em: 3 jul. 2020.

KUDRIAVTSEV, S. V. Zarubezhnie filmi v sovietskom kinoprokate. Disponível em: http://kinanet.livejournal.com/13882.html\#cutid1. Acesso em: 3 maio 2016.

LOW, P. When Songs Cross Language Borders: Translations, Adaptations and “Replacement Texts". The Translator, v. 19, n. 2, p. 229-244, 2013.

POLÊNOVA, L. Guenerali pestchanikh karierov. 2012. Live Journal. Disponível em: https://polenova.livejournal.com/348638.html. Acesso em: 3 maio 2016.

PUTIN, Vladimir. Vladimir Putin. Istoria jizni (Ulitsa pestchanikh karierov). Izvestiia, Moscou, 17 jan. 2002, p. 7.

SENKIN, B. Hall Bartlet i ego “guenerali”, Rovesnik, p. 23, ago. 1974.

SLIVNIAK, M. Perevod pesni iz filma Generali pestchanikh karierov. 2017. Stihi.ru. Disponível em: https://stihi.ru/2017/05/28/1088. Acesso em: 3 maio 2016 Spissok zarubejnikh filmov v prokate SSSR po 1991 g. 2008. Disponível em: http://fenixclub.com/index.php?showtopic=119228. Acesso em: 3 maio 2016 SUSAM-SARAJEVA, S. Translation and Music. The Translator, v. 14, n. 2, p. 187-200, 2008.

VETROVA, T., "Publika aplodiruet". Kinematograf Latinskoi Ameriki. Versha svoiu sudbu, Moscou, Izdatelstvo Kanon-Plius Reabilitatsya, 2010.

\section{Resumo}

Na União Soviética, a música "Suíte dos Pescadores" se tornou conhecida devido à enorme popularidade do filme The Sandpit Generals (Capitães da Areia), produção norte-americana baseada na obra de Jorge Amado e que influenciou gerações inteiras - inclusive o atual presidente, Vladímir Pútin. Mas a versão 
russa que se disseminou após os anos 1970, intrinsecamente ligada ao argumento do filme, não tinha nada a ver com a original. Neste artigo, analisamos como o replacement text - como descreve Low esse tipo de material - imperou para o estabelecimento da obra de Caymmi na Rússia.

Palavras-chave: Dorival Caymmi; Música brasileira; Tradução musical; Texto de substituição.

\begin{abstract}
In the Soviet Union, Caymmi's song, "Suite dos Pescadores", became wellknown due to the enormous popularity of the film The Sandpit Generals, an American production based on Jorge Amado's work which influenced entire generations - including the current president, Vladimir Putin. But the Russian translation of the song that became known in the 1970s, intrinsically linked to the film's plot, greatly differ from the meaning of the original lyrics. In this article, we analyze how the "replacement text" - as Low describes this type of material - prevailed for the reception of Caymmi's work in Russia.
\end{abstract}

Keywords: Dorival Caymmi; Brazilian music; Musical translation; Replacement text.

\begin{abstract}
Аннотация
В Советском Союзе песня Каимми «Суита (Марш) Рыбаков» стала известной благодаря огромного успеха фильма «Генералы песчаных карьеров», производства США и основанный на романе Жоржи Амаду, который оказал влияние на целые поколения, включая нынешнего президента Владимира Путина. Однако русская версия, получившая распространение в 70-х и непосредственно связанная с главное идей фильма не имеет ничего общего с оригиналом. В этой статье анализируется, как «заменены текст» - как называет Питер Лоу этот тип материала - стало решающей для установления творчества Каимми в России.
\end{abstract}

Ключевые слова: Доривал Каимми, бразильская музыка, замена текст песен, замена в текстах 